\title{
Assessment of the effects of community participation on sustainable development in Rwanda: A case of Water Aid Rwanda project in Gahanga Sector, Kicukiro District
}

\author{
James Mutanguha ${ }^{1}$ and Dr. James Kant Kamuhanda ${ }^{2}$ \\ ${ }^{1,2}$ School of Business and Economics, Mount Kenya University, \\ Kigali, Rwanda
}

\begin{abstract}
This study aimed to assess the effect of community participation on sustainable development in Rwanda. A case of WaterAid Rwanda project in Gahanga Sector Kicukiro Distrct. It examined the level of community participation in WaterAid project, assessed the level of sustainability of WaterAid project, as well the effect of community participation on sustainability of WaterAid Rwanda Project in Gahanga Sector, and relationship between variables. The study adopted a descriptive design and coefficient of correlation to measure effects size $-r$ with a mixed approach. A sampled size of 383 was drawn from a target population of 6891. The study used simple random and census sampling techniques. Questionnaire, interview guide and desk review were used using statistical package for social sciences for data analysis. The study felt that all variable values are above the standard point and community members recorded a mean of 3.5 for participation in project initiation. The study has shown that respondents recorded a mean of 4 for participation in cost sharing and furthermore recorded a mean of 3.8 for participation in management and protection of WaterAid Rwanda project in Gahanga Sector, Kicukiro District. the results reveals that $49.2 \%$ of respondents with a mean of 3.6 and standard equal to 1.3 felt a very high with the statement of repair to damaged infrastructure provided by WaterAid Rwanda. Also results revealed that $35.6 \%$ of respondents with a mean of 3.4 and standard equal to 1.5 felt a very high with the statement of Participation in WaterAid Rwanda project initiation The correlations between community participation and sustainability of WaterAid Rwanda project were statistically significant given that, the $\mathrm{p}$ values were $<0.05$ and $<0.01$. The implication was that high levels of community participation within WaterAid Rwanda project would significantly enhance the
\end{abstract}

sustainability of the project. The study recommends that Non-Governmental organizations in Rwanda who are considered to be executors of projects, to focus on establishment of understanding among citizens about the projects and encourage community involvement the entire project cycle, putting more emphasis on community participation at project initiation phase in order attain project sustainability after withdrawal of the funds.

Keywords: Community, Participation, Sustainable development, WaterAid Rwanda

\section{Introduction}

One of the growing problem in developing countries is unsustainability of projects (Rietbergen, 2013). A number of non-government organization projects were executed by local government, World Bank and other agencies through the top down model, however, local community members were not involved in any stage of the program life cycle. This resulted into insufficient impact on targeted beneficiaries as $40 \%$ of project intervention are not being sustained for one to two years after the withdrawal of funds. A low percentage of goods and services are maintained and delivered after 5 years of termination of execution of a project, stagnation of local action stimulated by the project and inability to generate successor services and initiatives as a result of project (Gaventa,\& Barrett,2010).

In search of ways to improve project sustainability, it was contended that active involvement of local community members can be an effective approach (Ismail, 2011). In Rwanda, the direct involvement of ordinary people in project initiation, cost sharing and management and maintenance of programs at grassroots level, has become an integral part of WaterAid in Kicukiro district Gahanga sector 
(MINALOC 2012). However, many researches have been carried out in the area of community participation, but the best of researcher knowledge little has been conducted in the context of Rwanda. Secondly, little has been undertaken to assess the impact of community participation using participatory approach such as project initiation, cost sharing, management and protection for sustainability of WaterAid project.

\section{Review of Literature}

Past studies on community participation recommended to undertake projects that are responding directly to people's expectation in delivering public utilities such as the provision of water. In fact, access to information ameliorate the living conditions for individuals and the entire community (Moehler, 2010). A study conduct in Philippine show that the irrigation authority argued that project for irrigation should involve local population. The role of this involvement was to increase production, outcomes and the results discovered to dominate the scene. The percentage ranged from $10 \%$ to $22 \%$ for the production of water and adjustment for organizational strategies Nwankwo (2011).

A study carried out in Nepal on small farmer development project (SFDP) validated the positive effects of community participation. This project in Nepal improved agricultural produces, loans repayment at the rate of $90 \%$ and socio-economic development. This improved income growth, sustain environment and population growth (Nwankwo, 2011). In the domain of property rights, it was advanced that ownership in decision making is very important for project performance (Phimphanthavong, 2012). The hypothesis is more likely to be that external involvement in identifying the needs and solutions to local problems is meaningless, it is advised to have local involvement. But this was ineffective due to corruption and discrepancy in responsibilities (Ghai, \& Vivian, 2014). A study conducted in Pakistan by the Orangi project inauguration for resolving local problems in Karachi, which enable people to access financial services and building their own facilitates in local management abilities for shelter, health status, family and education and other activities (Phimphanthavong, 2012). Based on the conceptual approach of Grameen Bank in Bangladesh is an organization with participatory approach at local level. This king of community banks increased the local people condition of living (Ugochukwu, 2010).

In India, community participation approach was used in Gujart forest project. In 1980s more than 18,000 offenses were recorded. The conservation organization decided to include local people in managing project. (Wild \& Harris, 2011). A study on 121 rural water project in developing countries asserted that people involvement in effective project execution. For this perspective, involvement in making decision of the project encourages effective's results (Zaden, 2010), also examines water projects in Sub Saharan Africa and finds that even if communities are initially successful in creating the project, they may lack the material resources and the connections to sustain their efforts. The maintenance of community infrastructure is often crucially dependent upon external agents. Thus the need for a well-functioning state apparatus does not seem to disappear with active community involvement. In Kenya, the Ministry of Agriculture (MoA) implicates local people in in conserving water, forest and biodiversity. The collaboration between the entire community and staff members of projects are beneficial in terms of production, decrease of environmental resource degradation (Naiga, et al., 2012).

In Rwanda, the Ministry of infrastructure (2016) argued the adoption of local population involvement in definition, plan, making decision and follow up on project management. In order to integrate community in water policy making, government of Rwanda implemented strategic policies related to new infrastructures and major rehabilitation of works. Community contribution is also related to their commitment and ownership. Community in development is still very vital for managing water sources. The community having been involved in planning, they must also be involved in the implementation of the planned activities for more ownership. Community-based management is still participatory approach to encourage the sustainability of water sources by safeguarding streams and shafts with drives (Ministry of infrastructure, 2016).

\section{Materials and Methods}

The population of the research was 6891 and a sample size of 383 was considered comprised Gahanga sector WaterAid project beneficiaries and four key informants, which included cells executives of Gahanga sector, Kicukiro district-Rwanda. The sample size was selected using census and simple random sampling technics. The study drafted clear and specific questionnaires containing questions and interviews which were held with key informants

\section{Results and Discussion}

The study presented the views of respondents in relation to the features of community participation in order to facilitate making of relevant conclusions in relation to the study. The researcher intended to 
examine the level of community participation in WaterAid Rwanda Project in Kicukiro District, Gahanga sector, assess the level of sustainability of
WaterAid Rwanda project in the sector and to establish the effect of community participation on sustainability of WaterAid Rwanda Project.

\subsection{Level of Community Participation in Water Aid Project}

Table 4. 1 Community Participation in Initiation of Water Aid Project

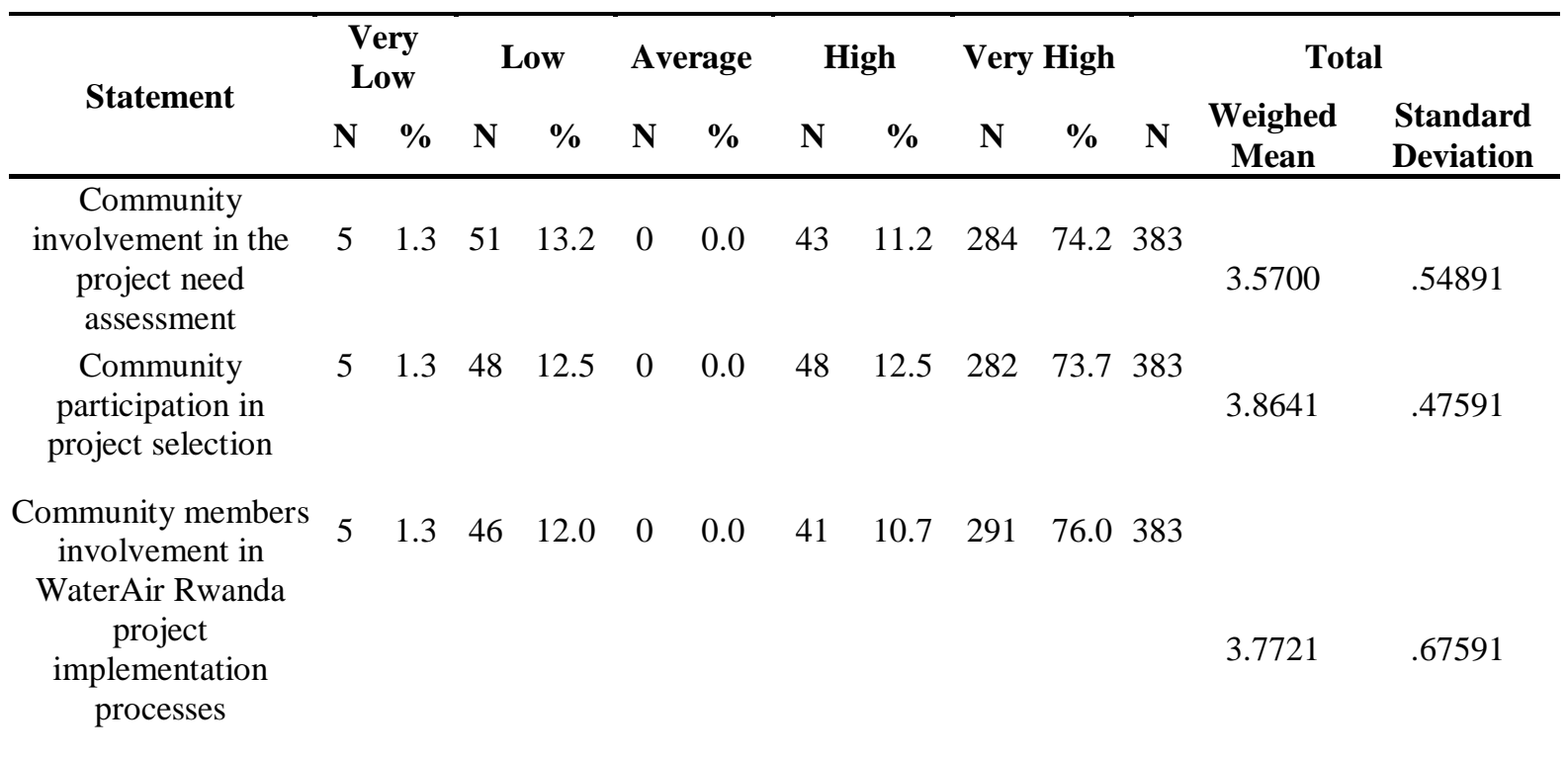

\section{Source: Primary Data (2020)}

From the findings, $74.2 \%$ demonstrated a very high participation in the project need assessment, $11.2 \%$ demonstrated a high level while $13.3 \%$ a low level, and $1.3 \% \mathrm{~s}$ very low level of participation in the in the project need assessment. This indicates that $85.4 \%$ of the respondents have participated in the project needs assessment. Findings on the level of

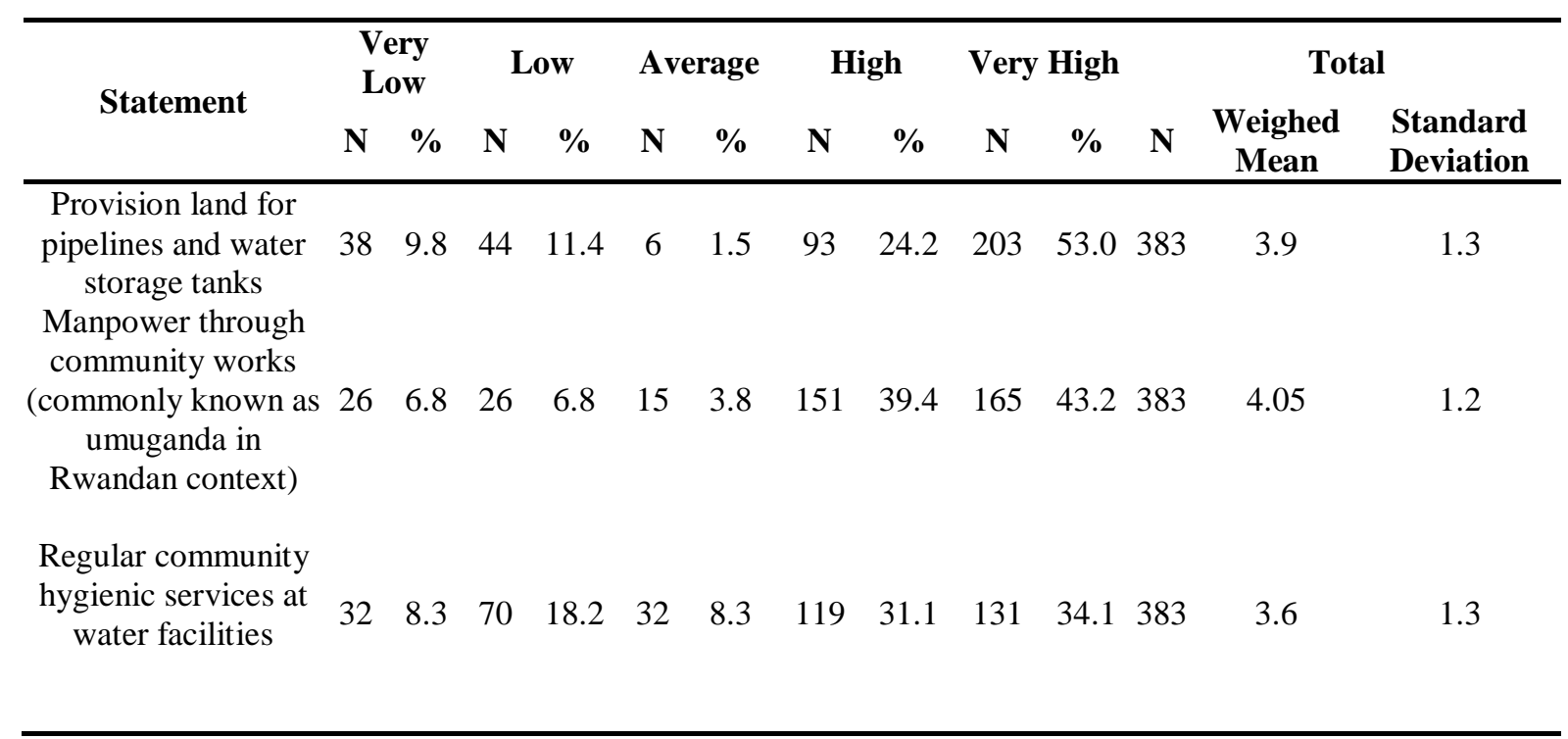

Source: Primary Data (2020)

participation in project selection indicates that $73.6 \%$ reveal a very high level of participation in in project selection , $12.5 \%$ high , $12.5 \%$ a low level and $1.3 \%$ a very low level. This implies that, $86.1 \%$ of respondents participated in project selection.

Table 4.2 Community Participation in Cost sharing of Operations and Maintenance 
The study findings on the level of participation in project implementation process, the finding established that, $76 \%$ of respondents demonstrated a very high level of participation in the project implementation process, $10.7 \%$ high, $12 \%$ low and $1.3 \%$ very low participation. This implies that $86.7 \%$ of respondents have participated in WaterAid Rwanda Project implementation in their area. The overall results from respondents demonstrated a high level of community participation in the project initiation of WaterAid Rwanda Project

Results revealed that $53.8 \%$ of respondents demonstrated a very high involvement in cost sharing through provision of land for pipelines and water storage tanks. While $43.2 \%$ of assessed respondents pointed out that community participation in cost sharing of operation and maintenance is done by giving manpower services through regular community works. The smaller number of respondents urged that cost sharing of operation and maintenance is through the provision of hygienic services. The study findings implied that cost sharing of operation and maintenance is realized through the provision of land for pipelines and water storage tanks

- Table 4. 3 Community Participation in Management and Protection of Rural Water Services

\begin{tabular}{|c|c|c|c|c|c|c|c|c|c|c|c|c|c|}
\hline \multirow{2}{*}{ Statement } & \multicolumn{2}{|c|}{$\begin{array}{l}\text { Very } \\
\text { Low }\end{array}$} & \multicolumn{2}{|c|}{ Low } & \multicolumn{2}{|c|}{ Average } & \multicolumn{2}{|c|}{ High } & \multicolumn{2}{|c|}{ Very High } & \multicolumn{3}{|c|}{ Total } \\
\hline & $\mathbf{N}$ & $\%$ & $\mathbf{N}$ & $\%$ & $\mathbf{N}$ & $\%$ & $\mathbf{N}$ & $\%$ & $\mathbf{N}$ & $\%$ & $\mathbf{N}$ & $\begin{array}{c}\text { Weighed } \\
\text { Mean }\end{array}$ & $\begin{array}{l}\text { Standard } \\
\text { Deviation }\end{array}$ \\
\hline $\begin{array}{l}\text { Establishment of } \\
\text { local water } \\
\text { management } \\
\text { committees }\end{array}$ & 18 & 4.7 & 20 & 5.3 & 6 & 1.5 & 136 & 35.6 & 205 & 53.0 & 383 & 4.2 & 1.0 \\
\hline $\begin{array}{c}\text { Regular maintenance } \\
\text { of water supply } \\
\text { facilities }\end{array}$ & 15 & 3.8 & 29 & 7.6 & 9 & 2.3 & 154 & 40.2 & 177 & 46.2 & 383 & 4.1 & 1.05 \\
\hline $\begin{array}{c}\text { Protection of } \\
\text { pipeline, water tanks } \\
\text { and storage }\end{array}$ & 32 & 8.3 & 29 & 7.6 & 11 & 3.0 & 162 & 42.4 & 148 & 38.6 & 383 & 3.9 & 1.2 \\
\hline
\end{tabular}

Source: Primary Data (2020)

Findings witness that $46.2 \%$ of respondents demonstrated a very high level of establishment of local water management committees, findings has shown that $38.6 \%$ a high level of participation in regular maintenance of water supply facilities while $50.3 \%$ pointed out that community members are involved in protecting pipeline, water tanks and storage. Findings implies that the community members ensure protection of water services through establishment of local water management committees, regular maintenance of water supply facilities and protection of pipeline, water tanks and storage, this was confirmed by interviewed sector local leader in Gahanga Sector

\subsection{Level of Sustainability of WaterAid Rwanda project in Gahanga Sector}

Table 4. 4 Affordability to Water by Local Community

\begin{tabular}{|c|c|c|c|c|c|c|c|c|c|c|c|c|}
\hline \multirow{2}{*}{$\begin{array}{l}\text { Statement } \\
\text { Free access to water is granted }\end{array}$} & \multicolumn{2}{|c|}{$\begin{array}{l}\text { Very } \\
\text { Low }\end{array}$} & \multicolumn{2}{|c|}{ Low } & \multicolumn{4}{|c|}{ AverageHigh } & \multicolumn{2}{|c|}{$\begin{array}{l}\text { Very } \\
\text { High }\end{array}$} & $\begin{array}{l}\text { Total } \\
\quad \text { Weighed }\end{array}$ & \multirow{2}{*}{$\begin{array}{l}\text { Standard } \\
\text { Deviation }\end{array}$} \\
\hline & $\mathbf{N}$ & $\%$ & $\mathbf{N}$ & $\%$ & $\mathbf{N}$ & $\%$ & $\mathbf{N}$ & $\%$ & $\mathbf{N}$ & $\%$ & N Mean & \\
\hline $\begin{array}{l}\text { Free access to water is granted } \\
\text { to every citizens in the sector as } \\
\text { a subjective rights. } \\
\text { There is a sufficient level of } \\
\text { consumption for all citizens }\end{array}$ & 75 & 19.7 & 79 & 20.5 & 35 & 9.1 & 136 & 35.6 & 58 & 15.2 & 3833.06 & 1.40 \\
\hline $\begin{array}{l}\text { Equal distribution of water } \\
\text { facilities to all community } \\
\text { members }\end{array}$ & & 6.8 & 26 & 6.8 & 15 & 3.8 & 151 & 39.4 & 165 & 43.2 & 3834.05 & 1.2 \\
\hline
\end{tabular}

Source: Primary Data (2020) 
As reflected, $35.6 \%$ favoured community members in upholding free access to water granted to every citizens in the sector as a subjective rights and $53.8 \%$ said that community access to water was realized through a sufficient level of consumption for all citizens, while $43.2 \%$ concluded that there was equal distribution of water facilities to all community members. The results implies that access to water in Gahanga sector was mainly upheld granting free water to every citizens in the sector as a subjective rights and there is a sufficient level of consumption for all citizens and there an equal distribution of water facilities to all community members.

Table 4. 5 Continuation of Local Activities

\begin{tabular}{|c|c|c|c|c|c|c|c|c|c|c|c|c|c|}
\hline \multirow{2}{*}{ Statement } & \multicolumn{2}{|c|}{$\begin{array}{l}\text { Very } \\
\text { Low }\end{array}$} & \multicolumn{2}{|c|}{ Low } & \multicolumn{2}{|c|}{ Average } & \multicolumn{2}{|c|}{ High } & \multicolumn{2}{|c|}{$\begin{array}{l}\text { Very } \\
\text { High }\end{array}$} & \multicolumn{3}{|c|}{ Total } \\
\hline & $\mathbf{N}$ & $\%$ & $\mathbf{N}$ & $\%$ & $\mathbf{N}$ & $\%$ & $\mathbf{N}$ & $\%$ & $\mathbf{N}$ & $\%$ & $\mathbf{N}$ & $\begin{array}{c}\text { Weighed } \\
\text { Mean }\end{array}$ & $\begin{array}{l}\text { Standard } \\
\text { Deviation }\end{array}$ \\
\hline $\begin{array}{l}\text { Water supply facilities are } \\
\text { adequately maintained }\end{array}$ & 72 & 18.9 & 55 & 14.4 & 9 & 2.3 & 136 & 35.6 & 110 & 28.8 & 383 & 3.4 & 1.5 \\
\hline $\begin{array}{l}\text { Community members } \\
\text { continued to provide their } \\
\text { manpower }\end{array}$ & 26 & 6.8 & 23 & 6.1 & 11 & 3.0 & 162 & 42.4 & 160 & 41.7 & 383 & 4.0 & 1.1 \\
\hline $\begin{array}{l}\text { Local leaders continued to } \\
\text { monitor water supply system in } \\
\text { this sector }\end{array}$ & 61 & 15.9 & 75 & 19.7 & 9 & 2.3 & 102 & 26.5 & 136 & 35.6 & 383 & 3.4 & 1.5 \\
\hline
\end{tabular}

\section{Source; Primary Data (2020)}

Results reveals that $35.6 \%$ felt a very high with the statement that water supply facilities are maintained after termination of WaterAid Rwanda support. This was also emphasized by key informants during an interview with the country director of WaterAid Rwanda who revealed that water maintenance was continued to be done by local communities, 41.7show a very high perception that people continued to provide their manpower works. It was also indicated that, among the main indicators that guarantee sustainability, respondents agree with the stamen that community members continued to give their manpower through regular community works.

Table 4. 6 Generation of successor services after Termination of WaterAid Rwanda Services

\begin{tabular}{cccccccccccccc}
\hline \multirow{2}{*}{ Statement } & \multicolumn{3}{c}{ Very Low } & \multicolumn{3}{c}{ Low } & \multicolumn{3}{c}{ Average } & \multicolumn{3}{c}{ High } & \multicolumn{2}{c}{ Very High } & \multicolumn{3}{c}{ Total } \\
& $\mathbf{N}$ & $\mathbf{\%}$ & $\mathbf{N}$ & $\boldsymbol{\%}$ & $\mathbf{N}$ & $\mathbf{\%}$ & $\mathbf{N}$ & $\boldsymbol{\%}$ & $\mathbf{N}$ & $\boldsymbol{\%}$ & $\mathbf{N}$ & Mean & Std \\
\hline Repaired damaged infrastructure & 38 & 9.8 & 32 & 8.3 & 79 & 20.5 & 112 & 29.2 & 188 & 49.2 & 383 & 3.6 & 1.3 \\
Greasing of infrastructure & 23 & 6.1 & 26 & 6.8 & 9 & 2.3 & 154 & 40.2 & 151 & 44.7 & 383 & 3.7 & 1.1 \\
Consistence of water availability & 26 & 6.8 & 26 & 6.8 & 15 & 3.8 & 151 & 39.4 & 165 & 43.2 & 383 & 4.05 & 1.2 \\
\hline
\end{tabular}

Source: Primary Data (2020)

Results reveals that $49.2 \%$ felt a very high with the statement with repaired damaged infrastructure provided by WaterAid Rwanda. More to that respondent's equivalent to $44.7 \%$ with a mean of 3.7 , standard deviation of 1.1 show a very high towards greasing of infrastructure which helps the farmers to

\subsection{Effect of Community Participation on Sustainability of Water Aid project}

The third objective aimed to found out the correlation between community participation and sustainability of WaterAid Rwanda. The study measure the amount of available water in the area. This was emphasized by $43.2 \%$ of respondents with a mean equal to 4.05 , standard deviation equal to 1.2 felt a very high perception that there is a consistence of water availability in Gahanga sector after termination of WaterAid Rwanda project support. intended to find out whether community participation promotes sustainability of WaterAid Rwanda through participation in project initiation, cost sharing of operations, maintenance, management and protection of water supply facilities. 
Table 4. 7 Correlation Analysis

\begin{tabular}{|c|c|c|c|c|}
\hline & & $\begin{array}{c}\text { Generation } \\
\text { of successor } \\
\text { after termination } \\
\text { of project }\end{array}$ & $\begin{array}{c}\text { Continuation } \\
\text { of Local Activities }\end{array}$ & $\begin{array}{c}\text { Affordability to } \\
\text { Water by Local } \\
\text { Community }\end{array}$ \\
\hline \multirow{3}{*}{ Project Initiation } & $\begin{array}{c}\text { Pearson } \\
\text { Correlation }\end{array}$ & $.158^{*}$ & $.413^{*}$ & $.710^{*}$ \\
\hline & Sig.(2-tailed) & .015 & .037 & .024 \\
\hline & $\mathrm{N}$ & 383 & 383 & 383 \\
\hline \multirow{3}{*}{ Cost Sharing } & $\begin{array}{c}\text { Pearson } \\
\text { Correlation }\end{array}$ & $.705^{*}$ & $.530^{*}$ & $.271^{*}$ \\
\hline & Sig.(2-tailed) & .025 & .041 & .021 \\
\hline & $\mathrm{N}$ & 383 & 383 & 383 \\
\hline \multirow{3}{*}{$\begin{array}{c}\text { Management and } \\
\text { project }\end{array}$} & $\begin{array}{c}\text { Pearson } \\
\text { Correlation }\end{array}$ & $.323^{*}$ & .081 & $.235^{* *}$ \\
\hline & Sig.(2-tailled) & .023 & .214 & .001 \\
\hline & $\mathrm{N}$ & 383 & 383 & 383 \\
\hline
\end{tabular}

Source: Researcher (2020)

There were positive correlation between participation in project initiation and generation of successor services after termination of project (r.158*, p.015), participation in project initiation and continuation of local activities (r.413*, p.037), participation in project initiation and access to water by local community (r.714, p.024). The correlations between participation in project initiation and generation of successor after termination of project, continuation of local activities and access to water by local community were statistically significant given that the $p$ values were $<0.05$ and $<0.01$. The implication was that high levels of participation in project initiation in WaterAid Rwanda in Kicukiro Distrcit, Gahanga sector would significantly enhance generation of successor services after termination of project, continuation of local activities and

\section{ownership. \\ Table 4. 8 Coefficients of correlation $-r$ measures the effects size}

There were positive correlation between cost sharing and generation of successor after termination of project (r.705*, p.025), cost sharing improved continuation of local activities (r.530* p.041),

There were correlations between management and protect and generation of successor services after termination of project, $\left(\mathrm{r} .323^{*}, \mathrm{p} .023\right)$, between management and protection and continuation of local activities (r. 235**, p .001). The correlations between management and protection and access to water by local community were statistically significant given that the $\mathrm{p}$ values were $<0.05$ and $<$ 0.01 . The implication was that high levels of management and protection within WaterAid Rwanda would significantly enhance generation of successor services after termination of project, continuation of local activities and access to water by local community.

\begin{tabular}{|c|c|c|c|c|c|}
\hline \multirow{2}{*}{ Model } & \multicolumn{2}{|c|}{ Unstandardized Coefficients } & \multirow{2}{*}{$\begin{array}{c}\text { Standardized } \\
\text { Coefficients } \\
\text { Beta }\end{array}$} & \multirow{2}{*}{$\mathbf{T}$} & \multirow{2}{*}{ Sig. } \\
\hline & B & Std. Error & & & \\
\hline Constant & .619 & .175 & & 3.3523 & .000 \\
\hline Project Initiation & .161 & .035 & .213 & 4.511 & .000 \\
\hline $\begin{array}{l}\text { Cost sharing of } \\
\text { operations and } \\
\text { maintenance }\end{array}$ & .279 & .038 & .358 & 7.382 & .000 \\
\hline $\begin{array}{l}\text { Management and } \\
\text { protection }\end{array}$ & .209 & .038 & .273 & 5.559 & .000 \\
\hline
\end{tabular}

\section{Source: Primary Data (2020)}

Results demonstrate the Coefficients of correlation $\mathrm{r}$ measures the effects size between dependent and independent variables. As SPSS create above table the equation is like this: 
$\mathrm{Y}=\mathrm{B} 0+\mathrm{B} 1 \mathrm{x} 1+\mathrm{B} 2 \mathrm{x} 2+\mathrm{B} 3 \times 3+\mathrm{B} 4 \mathrm{x} 4+\mathrm{e}$

$\mathrm{Y}=.619+.161 \times 1+.279 \times 2+.209 \times 3+.203 \times 4+\mathrm{e}$.

The study shows that participation in project initiation Beta coefficient is significant at $\mathrm{P}$-value .000 , constant if the value of Beta coefficient is 0.213 with $(\mathrm{T})$ value of 4.511 . This shows that keeping remaining 3 variable constant, if the researcher bring one unit change in participation in project initiation, the sustainability of WaterAid Rwanda will be changed by $21.3 \%$.

The participation in cost sharing of operation and maintenance Beta coefficient is significant at $\mathrm{P}$-value 0.000 . The value of Beta coefficient is 0.358 with $(\mathrm{T})$ value of 7.382. This shows that keeping remaining 3 variable constant, if the researcher bring one unit change in participation cost sharing of operations and maintenance, sustainability of WaterAid Rwanda will be about $35.8 \%$.The participation in management and protection of supplied water Beta coefficient is significant at P-value 0.000 . The value of Beta coefficient is 0.273 with (T) value of 5.559. This shows that keeping remaining 3 variable constant, if the researcher bring one unit change in participation in management and protection, the sustainability of WaterAid Rwanda will be about $27.3 \%$.

\section{Discussion}

This study concur with the findings of (Agbodike, et al., 2014) where, proper evaluation and understanding of community involvement can be better achieved when it is viewed against a theoretical framework built on initiation phase. But this contradicts with the study by Bukenya and King, 2012) that the sustainability of rural water projects is greatly affected by low degree of community participation in establishing water system from technological selection to the supply and management arrangement. These findings are against the study by Lieberman, et al., (2013) indicate that communities can participate by generating funds for spares if all are committed to water supply.

The study is against Bukenya, et al.,(2012) where the community participation in management and protection of project denotes the ability and commitment of beneficiaries to assume responsibilities, affect and assess the nature of service delivered by non-governmental organization. This study did not contradict the findings from a study carried out by (Ghai \& Vivian, 2014), where the community should be ready take on the fact water source should be affordable.

This research is relevant since, Bukenya and King (2012), the Sustainable development is also measured using the continuation of local activities. It was confirmed that a good project or program that is well implemented is more likely to be characterized with the continuation of local activities after the end

\section{ISSN 2455-6378}

of that project. At the same time, evidence is accumulating that properly supported communities have the ability and the willingness to manage their own water systems (Ghai \& Vivian, 2014). The study findings concur with the observations of Aladuwaka and Momsen (2010) who argued that in order to meet part of the goal, literature has shown that development practitioners in the sector were putting more attention on building new facilities than ensuring their sustainability.

The study also found out that, community participation has a significant effect on project sustainability. According to Chong, et al. (2013). Community participation has the effect of empowering the citizens so that they can continue to direct future changes and put pressure on outside forces to support these changes. The location of participatory work is thus focused on the community level and depends upon local interests and capacity to engage in action for change. This was made clear by the study findings, that community participation and project sustainability has a significant relationship.

\section{Conclusions}

The study was carried out in the context of Rwanda with the intention to show how community involvement may improve project sustainability of national and international NGOs in Rwanda, city of Kigali, Kicukiro Distrcit and Gahanga sector. From the findings, the study concludes that, participatory strategies have positive effect of project sustainability.

Participation in cost sharing affect the project sustainability the most. Secondly, participation in project management and maintenance, and thirdly participation in project initiation has the least effect on project sustainability. Correlation analysis, linear and multiple regression and interview results show that participation in project initiation, cost sharing planning and management and maintenance will help NGOs to achieve their development targets and will help project sustainability and overcome their problems.

The study recommends that Non-Governmental organizations in Rwanda who are considered to be executors of projects, to focus on establishment of understanding among citizens about the projects and encourage community involvement in the entire project cycle, putting more emphasis on community participation at project initiation phase, cost sharing of operations, management and protection, in order attain project sustainability after withdrawal of the funds. Government should set proper strategies to involve community members in decision making on development projects. NGOs' projects should be taking into consideration the most poor community members to improve their social welfare. 
Acknowledgments

I wish to acknowledge Dr. James Kant KANMUHANDA for having sacrificed his time and other commitments to guide me throughout the writing of this paper. I thank the staff and management of Mount Kenya University for their academic support. I cannot forget to thank the City of Kigali for their authorization to collect data in Gahanga sector of Kicukiro district.

\section{Reference}

[1] Agbodike, F. C., Igbokwe-Ibeto, C. J., \& Nkah, B. C. (2014). Local government administration and the challenges of sustainable development in Nigeria. Review of Public Administration and Management, 400(3615), 1-11.

[2] Aladuwaka, S. \& Momsen, J. (2010). Sustainable development, water resoaurces management and women ${ }^{\text {ee }}$ empowerment: The

[7] Institute Development Studies, Working Paper, vol. 210 , no. 347 ,

[8] Ghai, D., \& Vivian, J. (2014). Grassroots environmental action: people's participation in sustainable development. London: Routledge.

[9] Ismail O. A. (2011). Civic education: A veritable tool for promoting responsible citizenship in Nigeria, Nigerian Jaganather union Parishad. A master thesis in the Department of General and Continuing Education, North South University, Bangladesh. Journal of Social Studies, XIV (2), 68-76

[10] Lieberman, E, Posner, D \& Tsai, L. (2013). 'Does Information Lead to More Active Citizenship? Evidence from an Education Intervention in Rural Kenya' March 5, MIT Political Science Department Research Paper no. 2, Princeton University Press, USA.

[11] Ministry of Infrastructure [MININFRA]. (2016). National water supply policy. Kigali: Rwanda.

[12] Ministry of Local Government (MINALOC).(2013). Law determining the organization and functioning of decentralized administrative entities. Kigali, Rwanda
Wanaraniya water project in Sri Lank. Gender \& Development, 18(1), pp.43-58. 2.

[3] Bukenya, B \& King, S. (2012). 'The contextual factors for demand-side social accountability an annotated Bibliography produced for the Social Accountability and Demand for Good Governance Cluster at the World Bank,

[4] Bukenya, B, Hickey, S and King, S. (2012). 'Understanding the role of context in shaping social accountability interventions: towards an evidence-based approach', Institute of Development Policy and Management, University of Manchester,

[5] Chong, A, De La O, A, Karlan, D, \& Wantchekon, L. (2013). 'Looking Beyond the Incumbent: The Effects of Exposing Corruption on Electoral Outcomes', Yale and Princeton Universities,

[6] Gaventa, J, \& Barrett, G. (2010). 'So what difference does it make? Mapping the outcomes of Citizen Engagement',

[13] Moehler, D. (2010). 'Democracy, Governance and Randomized Development Assistance' Annals of the American Academy of Political and Social Science, vol. 628 no. 30,

[14] Naiga, R., Penker, M., \& Hogl, K. (2012). From supply to demand driven water governance: challenging pathways to Safe Water Access in Rural Uganda. Kampala: Uganda

[15] Nwankwo, O. (2011).The August meeting concept and community development in Nigeria, West Africa insight available at http://www.westatrianshight.orgh/artcicles/adtl

[16] Phimphanthavong, H. (2012). The Sustainable Development through Community Participation: Case of Poverty Reduction Fund Project in Laos.

[17] Zaden, B.S. (2010). Participation and community development: Current Research Journal of Social Science, 2 (1), 13-14.

[18] Wild, L \& Harris, D. (2011), 'The political economy of community scorecards in Malawi. World Bank. New York. USA.

[19] Ugochukwu, C. (2010). The role of women in national development: National Council of Women Societies 